\title{
VOLTO SEMANA QUE VEM: DEMOCRACIA ACIMA DE TUDO!
}

\section{VOLTO SEMANA QUE VEM: DEMOCRACY ABOVE ALL!}

\author{
Isis Milreu' \\ [https://orcid.org/0000-0001-9142-1406] \\ DOI: 10.30612/raido.v14i35.12179
}

\begin{abstract}
RESUMO: Percebemos que nas últimas décadas houve um crescimento significativo de ficçōes latino-americanas que recriaram episódios das ditaduras implantadas em nosso continente no século passado. No Brasil, destaca-se a narrativa Volto semana que vem (2015), da escritora gaúcha Maria Pilla. Em seu livro, a autora rememora acontecimentos de sua infância e juventude, bem como de sua militância, marcada pela prisăo na Argentina e pelo exílio na França. Consideramos que a ficçăo de Pilla possibilita um produtivo diálogo entre a literatura e a história da América Latina, uma vez que traz à tona relatos de personagens que resistiram aos regimes cívico-militares no Cone Sul. Assim, examinaremos neste estudo como a escritora ficcionalizou os vergonhosos episódios ocorridos em nosso continente durante os regimes de exceçăo. Acreditamos que as violaçôes aos direitos humanos que foram praticadas nos governos ditatoriais năo podem ser esquecidas e pensamos que é necessário exercermos o nosso dever de memória, conforme proposto por Ricouer (2007). Nesse sentido, o presente estudo visa contribuir para a preservaçấo das memórias dos defensores da democracia, as quais correm o risco de desaparecer da dita história oficial. Entre os nossos referenciais teóricos encontram-se Dalcastagné (1996), Esteves (2010), Prado e Pelegrino (2016), Figueiredo (2017), entre outros.
\end{abstract}

Palavras-chave: Literatura brasileira contemporânea; América Latina; Ditadura, resistência, mulheres e política; Literatura, história e memória; Maria Pilla.

ABSTRACT: In the last decades it has been noticed a significant growth of Latin American fictions which have recreated dictatorships established in our continent last century. In Brazil, Maria Pilla's Volto semana que vem [I will be back next week] (2015) emerges as an important one. In her book, the author recollects events of her childhood and youth, as well as memories of her militancy which was marked by periods in jail in Argentina and exile in France. We consider that Pilla's fiction makes it possible a productive dialog between literature and history in Latin America, as it brings up characters' accounts which portray resistance towards civic and military regimes in the Southern Cone. Thus, we intend to examine how the writer has fictionalized the shameful episodes in our continent during regimes of exception. We believe that human rights violations practiced by dictatorial governments cannot be forgotten. Instead, we think of the necessity to practice our duty of memory, following Ricouer (2007).

Professora de Literaturas Hispânicas, da Unidade Acadêmica de Letras da Universidade Federal de Campina Grande - UAL. 
In this sense, this study aims at contributing to memories preservation of democracy defenders, since they are at risk of being erased from the so-called official history. Our theoretical framework is supported by Dalcastagné (1996), Esteves (2010), Figueiredo (2017), Prado and Pelegrino (2016), among others.

Keywords: Contemporary literatura brazilian; Latin America; Dictatorship, resistance, women and policy; Literature, history and memory; Maria Pilla.

\section{PALAVRAS INICIAIS}

"Acho que valeu a pena o conjunto da luta da sociedade brasileira. A aventura militar custou caro ao país, mas acabou se rendendo ao óbvio. Por mais defeitos que tenha, a democracia ainda é o regime que pode melhor defender os interesses da cidadania." (PILLA, 2015, s. /p.)

Oficialmente, a ditadura cívico-militar brasileira começou em 1964 e terminou em 1985, mas suas marcas ainda estâo presentes em nossa sociedade. Na apresentaçáo do livro 0 que resta da ditadura: a exceçăo brasileira, Edson Teles e Vladimir Safatle (2010, p.9) assinalam que o regime de exceçăo encontrou uma forma "[...] de permanecer em nossa estrutura jurídica, em nossas práticas políticas, em nossa violência cotidiana, em nossos traumas sociais que se fazem sentir mesmo depois de reconciliaçóes extorquidas." Nesse sentido, apontam que muitos problemas da atualidade se originaram ou se acentuaram no período ditatorial.

Além disso, a luta pelos direitos à memória, verdade e justiça continua até hoje, pois ainda năo sabemos o paradeiro de vários desaparecidos e os responsáveis por diversos crimes contra a humanidade cometidos nesse período ainda năo foram julgados. Uma das principais razôes para que essas atrocidades continuem impunes é o fato de as Forças Armadas, apoiadas pela Lei da Anistia promulgada em 1979, nâo assumirem sua responsabilidade institucional diante dos delitos praticados durante o regime autoritário. Dessa forma, ao năo realizarem uma autocrítica e năo disponibilizarem os seus arquivos para o público, a instituiçâo protege os agentes que colaboraram com a ditadura e impede que o país acerte as contas com o seu passado vergonhoso.

Há mais de vinte anos, no livro $O$ espaço da dor (1996), Regina Dalcastagné denunciou que os repressores estâo soltos e parecem felizes. Afinal, "'E um homem impune, e sempre que lembra disso ele sorri. Sorri de nosso esquecimento, sorri diante da perplexidade daqueles poucos que ainda se recordam, que ainda sofrem. Sorri por todos os sorrisos que roubou." (DALCASTAGNÉ, 1996, p.16). A autora afirma que se trata do sorriso dos canalhas e sustenta que temos a obrigaçấo de năo esquecer os abusos que cometeram, visto que

Em 21 anos de ditadura foram tantos os mortos, os torturados e os humilhados que faltaria espaço onde refugiar toda a sua dor. A memória, terreno tăo propício, é demasiadamente instável para semelhantes horrores. Talvez por isso os homens inventaram a arte. (DALCASTAGNÉ, 1996, p.16).

A estudiosa acrescenta que no Brasil os responsáveis por criar um espaço de acolhimento para essas dores foram os escritores, dado que "É nos romances que vamos reencontrar, com maior intensidade, o desespero daqueles que foram massacrados por acreditarem que podiam fazer alguma coisa pela história de nosso país." (DALCASTAGNÉ, 1996, p.16). Logo, o papel de investigar, denunciar e julgar as citadas 
barbáries, o qual deveria ter sido desempenhado pelo estado brasileiro, foi assumido por muitos ficcionistas que preservam as memórias desse momento atroz de nossa história em suas obras.

Por sua vez, no artigo "Literatura e ditadura", o escritor Ricardo Lísias (2018, s. /p.) aponta que "[...] a literatura brasileira realizada desde a redemocratizaçấo acompanha o mal-estar que essa situaçăo de impunidade gerou ou, por outro lado, alia-se à política oficial que quer ver a "página virada" sem esclarecer o que realmente aconteceu." Nessa ótica, a literatura reproduz a dicotomia que está instaurada em nossa sociedade, uma vez que o literato precisa tomar partido, seja pela denúncia ou pelo encobrimento das atrocidades cometidas durante a ditadura, rompendo ou colaborando com a política de apagamento do nosso passado traumático.

Lísias (2018, s. /p.) ressalta que hoje a ditadura voltou a ser discutida de forma mais concreta pela ficçăo, motivada nâo só por razôes estéticas, mas também porque o "[...] próprio estado de absoluto descaso das instituiçóes para com a necessidade tâo elementar de justiça colabora para que alguns autores estejam se voltando para o problema." Assim, vários escritores brasileiros contemporâneos estâo denunciando a ineficácia do estado em garantir os direitos básicos das vítimas da ditadura e de seus familiares. Desse modo, contribuem para a recuperaçấo das vivências de setores que, muitas vezes, estâo excluídos da dita história oficial.

Entendemos que, ao ficcionalizarem os traumáticos episódios ocorridos no regime militar, nossos autores cumprem o seu dever de memória, definido por Paul Ricouer (2007, p.101), como “[...] o dever de fazer justiça, pela lembrança, a um outro que náo a si." No livro A literatura como arquivo da ditadura brasileira, Eurídice Figueiredo (2017, p.13) explica que "[...] o trabalho de investigaçăo e divulgaçăo do que ocorreu nos porōes da ditadura é um dever de memória em relaçăo às vítimas, a seus familiares e à sociedade em geral." Em suma, é necessário lembrar suas histórias para combater o esquecimento e proporcionar justiça, mesmo que simbólica, aos que lutaram pela democracia em nosso país.

Uma das possibilidades de praticarmos o nosso dever de memória é investigar como a ditadura foi recriada na literatura. Entre as ficçōes recentes que se dedicaram a abordar a história dos que combateram o regime autoritário brasileiro se destaca Volto semana que vem (2015), de Maria Pilla, publicada pela editora Cosac Naif, finalista do prêmio Jabuti na categoria romance 2016 e vencedora do prêmio Açorianos de Narrativa Longa, em 2015. Nessa obra, a escritora gaúcha rememora sua trajetória, relatando episódios de sua militância, da prisâo na Argentina e de seu exílio na França. Percebemos que a sua história pessoal está conectada com a de nosso continente, possibilitando uma produtiva aproximaçăo entre literatura, história e memória.

Acreditamos que este romance pode ser inserido no rol das ficçôes de autoras brasileiras que abordam o regime ditatorial. Entre elas, encontram-se Nicoleta Ninfeta (1973), de Cassandra Rios; As meninas (1974) e As horas nuas (1989), de Lygia Fagundes Telles; A república dos sonhos (1984), de Nélida Pińon; O torturador em romaria (1986), de Heloneida Studart; Tropical sol da liberdade (1988), de Ana Maria Machado; Nâo falei (2004), de Beatriz Bracher; $O$ fantasma de Buñuel (2004), de Maria José Silveira; A chave de casa (2007), de Tatiana Salem Levy; Azul corvo (2010), de Adriana Lisboa; Nem tudo é silêncio (2010), de Sonia Regina Bischain; Antes do passado: o silêncio 
que vem do Araguaia (2012), de Liniane Haag Brum; Mar azul (2012), de Paloma Vidal; Tempos extremos (2014), de Míriam Leităo; Palavras cruzadas (2015), de Guiomar de Grammont; Rio-Paris-Rio (2016), de Luciana Hidalgo; Outros cantos (2016), de Maria Valéria Rezende; Cabo de guerra (2016), de Ivone Benedetti; Aqui, no coraçâo do inferno (2016), O peso do coraçâo de um homem (2017), O Amor, esse obstáculo (2018), de Micheliny Verunschk, e O corpo interminável (2019), de Cláudia Lage.

Esta brevíssima relaçăo, a qual năo tem a pretensăo de ser definitiva, mas meramente ilustrativa, nos mostra que nossas escritoras têm se dedicado ao tema desde a década de 1970, desconstruindo a falácia de que as mulheres náo discutem ou escrevem sobre política. Também constatamos que houve um significativo crescimento de autoras brasileiras que se debruçaram sobre a ditadura na segunda década do século XXI. Nossa hipótese é que essa ampliaçăo de narrativas sobre o último período ditatorial no Brasil está relacionada com a criaçăo da Comissăo Nacional da Verdade (2011-2014), a qual deu visibilidade ao tema e proporcionou novos questionamentos sobre o nosso passado. Além disso, as afirmaçóes de Lísias (2018) sobre o mal-estar provocado nos escritores brasileiros contemporâneos pela impunidade contra os crimes cometidos no regime de exceçấo pode ser um dos fatores para o aumento de ficçôes de autoria feminina sobre a ditadura.

Retornando à narrativa de Pilla, interessa-nos registrar que a escritora gaúcha, ao contrário de alguns militantes que combateram os regimes de exceção e se frustraram, mostra-se orgulhosa de sua batalha. Em uma entrevista para o jornal Sul21 em 2015, ela reflete sobre a construçâo de seu livro e sua trajetória na militância, entre outras questōes. A epígrafe que abre nosso trabalho foi retirada dessa conversa, bem como as outras que inserimos nas demais partes, pois entendemos que elas contribuem para uma leitura da narrativa baseada em sua relaçăo com a história. No referido fragmento, a autora avalia que a luta da sociedade brasileira contra a ditadura, qualificada como aventura, valeu a pena. Ainda defende a democracia, a qual considera essencial para a construçáo da cidadania. Estamos de acordo com essa premissa e acreditamos que a salvaguarda do regime democrático deve ser realizada em todos os espaços possíveis, inclusive nos estudos literários. Apesar de sabermos que nossa democracia ainda apresenta sérios problemas, tais como a desigualdade social e a violência, pensamos que a soluçâo é aperfeiçoá-la e nâo revivermos desventuras antidemocráticas.

Tendo em vista as consideraçôes anteriores, o objetivo do presente trabalho é examinar como a história dos opositores aos regimes militares latino-americanos, particularmente as mulheres, é contada pela narradora-protagonista de Volto a semana que vem. O nosso estudo está dividido em quatro partes, além desta introduçấo. No primeiro tópico apresentamos alguns dados sobre os governos autoritários de nosso continente e sobre a anistia no Brasil. Já no segundo discutimos as relaçôes entre literatura, história e memória. A seguir, analisamos o romance de Pilla, destacando os episódios de resistência que foram ficcionalizados e evidenciando as suas relaçóes intertextuais. Por fim, traçamos as conclusōes de nossa investigaçáo examinando os procedimentos adotados pela autora gaúcha para reconstruir o período do terrorismo de estado no Cone sul na década de 1970. Entendemos que é necessário promover mais reflexóes sobre essa temática nos âmbitos em que atuamos a fim de contribuir para que a história dos combatentes da ditadura năo seja apagada ou distorcida e, evidentemente, que a democracia continue viva. 


\title{
CONSIDERAÇÕES SOBRE AS DESVENTURAS DITATORIAIS NA AMÉRICA LATINA E A ANISTIA NO BRASIL
}

\author{
"A anistia foi necessária para restabelecer o regime de direitos, permitindo a volta \\ dos exilados e a restituiçāo dos seus documentos. No entanto, ao contrário da Lei da \\ Anistia, nāo há simetria entre torturados e torturadores. O Brasil é até agora o país \\ da América Latina que ainda mantém as bárbaras leis de uma anistia incompleta."
}

(PILLA, 2015, s./p.)

Atualmente, em 2020, estamos passando por um momento crítico no mundo devidoà pandemia provocada pelo coronavírus. No Brasil, além de a nossa saúde estar ameaçada, ainda precisamos lutar pela permanência da democracia, uma vez que nos últimos anos e, inacreditavelmente, até durante o isolamento social, presenciamos manifestaçóes de alguns grupos que reivindicam publicamente intervençōes militares. Cabe frisar que a apologia à ditadura é crime, segundo a legislaçâo brasileira, mas os "canalhas" que hoje defendem o retorno ao autoritarismo continuam soltos e sorrindo, conforme alertou Dalcastagné (1996), agindo de forma violenta nas ruas e nas redes sociais.

Nesse contexto, consideramos necessário seguir denunciando as barbáries cometidas pelos regimes ditatoriais, năo somente em nosso país, mas também em outras partes da América Latina porque acreditamos na justiça e entendemos que para compreendermos nosso presente é fundamental conhecermos nosso passado. Além disso, a história de nosso continente é marcada por avanços e retrocessos no que se refere à consolidaçăo da democracia, possibilitando muitas reflexóes quando comparamos a trajetória dessas naçôes. Afinal, basta lembrar que somente na última década tivemos três golpes na América do Sul, para nos restringirmos ao âmbito de nossas fronteiras, nos quais os presidentes do Paraguai (2012), do Brasil (2016) e da Bolívia (2019) foram destituídos de seus cargos através de processos jurídicos questionáveis, sendo sucedidos por governos autoritários. Entendemos que o sistema democrático foi duramente atacado nesses países, embora a violência explícita das ditaduras implantadas no século passado tenha sido mascarada por um simulacro de legalidade.

Percebemos que muitos problemas que estamos enfrentando na contemporaneidade foram originados ou intensificados durante o regime cívico-militar (1964-1985). Um deles é a violência que se acentuou no período do horror e nâo foi devidamente investigada. Essa impunidade promoveu uma visăo errônea de que o autoritarismo pode ser justificado em algumas ocasiōes. Inferimos que essa concepçăo perpassa o funcionamento de alguns grupos de nossa sociedade, tal como as milícias que praticam açōes bárbaras, sem puniçâo, da mesma forma que ocorreu com os torturadores e assassinos do governo de exceçăo. Outro paralelo que podemos traçar entre as duas épocas refere-se à banalizaçăo da vida, uma vez que hoje escutamos abomináveis declaraçóes de políticos e de empresários que minimizam as mortes da populaçáo menos favorecida economicamente, decorrentes da pandemia de coronavírus.

Afora a violência visível, notamos a proliferaçâo de "intelectuais" que tentam relativizar as inúmeras atrocidades que marcaram a ditadura brasileira. Trata-se dos chamados "negacionistas", os quais consideram que o período de exceçāo apenas cumpriu o seu dever de libertar o país da "ameaça comunista", como se o terrorismo de estado pudesse ser justificado. Esse grupo, convenientemente, minimiza as graves violaçóes de direitos humanos praticadas durante o regime cívico-militar, as quais foram e sâo 
denunciadas por familiares, entidades e organismos nacionais e internacionais, historicamente comprometidos com a defesa da democracia.

Observamos que hoje, de forma parecida com o que ocorreu na época ditatorial, a figura do "comunista" está sendo usada para justificar perseguiçōes e, ironicamente, todos os que se opóem ao governo atual recebem essa denominaçấo por seus seguidores, independentemente de sua ideologia. Em História da América Latina (2016), Maria Lígia Prado e Gabriela Pellegrino registram que os regimes ditatoriais que se instauraram em nosso continente no século passado foram apoiados pelos Estados Unidos, visando, supostamente, combater a expansâo do "comunismo", depois do sucesso da Revoluçăo Cubana (1959). Prado e Pellegrino (2016, p. 168) assinalam que

\begin{abstract}
Centros de inteligência militar formados nessa época, em diferentes países, passaram a definir os contornos da chamada Doutrina de Segurança Nacional, voltada a um novo tipo de inimigo - o inimigo interno, imiscuído na sociedade e propagador de "ideias subversivas".
\end{abstract}

Desse modo, embasava-se legalmente a perseguiçăo aos opositores internos da ditadura, denominados oficialmente de "subversivos". O resultado dessa política arbitrária foi catastrófico, uma vez que na prática instalou-se o terror do estado, respaldado por parcelas da sociedade civil, e muitas pessoas foram presas, torturadas e até assassinadas por se oporem ao autoritarismo. Outras conseguiram se exilar e continuaram a combater a ditadura a partir dos países em que foram acolhidas. As estudiosas apontam que, apesar da violência extrema do aparato repressivo do estado, houve vários movimentos de oposiçấo aos governos ditatoriais em nosso continente, geralmente, ligados às organizaçôes de esquerda.

Também relatam que na década de 1980 a situaçâo da maioria dos regimes ditatoriais latino-americanos tornou-se insustentável, tanto política quanto economicamente, forçando o retorno à democracia. Identificamos que o processo de redemocratizaçăo se desenvolveu de maneira distinta nos países da América Latina e, consequentemente, marcou a forma como esses episódios traumáticos foram e estăo sendo tratados em cada naçâo de nosso continente.

Vale a pena registrar que a Argentina apurou os crimes contra a humanidade cometidos durante sua última ditadura desde o fim de seu período autoritário, através da instauraçáo, em 1983, da Comissăo Nacional sobre o Desaparecimento de Pessoas (CONADEP). Desde entâo, vários militares e civis argentinos que participaram das violaçóes aos direitos humanos foram investigados, julgados e condenados. Porém, no Brasil, a Comissăo Nacional da Verdade foi criada tardiamente, em 2011, e iniciou os seus trabalhos em 2012, apresentando o seu relatório final em 2014, ou seja, 50 anos após o início do regime cívico militar. Cabe frisar que sua implantaçăo só foi possível devido à mobilizaçâo de vários setores da sociedade civil. Aliás, é importante lembrar que graças às açôes dos grupos de resistência à ditadura em distintos momentos de nossa história temos elementos para apurar os abusos cometidos pelos repressores, como veremos a seguir.

Inicialmente, distingue-se o trabalho clandestino coordenado por Dom Paulo Evaristo Arns, pelo Rabino Henry Sobel e pelo Pastor presbiteriano Jaime Wright, respaldados pelo Conselho Mundial de Igrejas e pela Arquidiocese de Sáo Paulo, que foi responsável por coletar e analisar documentos, processos e relatos de torturas e 
violaçóes aos direitos humanos a partir de 1979. Os resultados desse levantamento estăo reunidos na publicaçâo Brasil: Nunca Mais que veio a público em 1985, quando o regime civil já havia sido restaurado no país. O objetivo dessa investigaçăo foi evitar que os processos judiciais movidos contra presos políticos fossem destruídos, preservando os registros e as memórias dessa época vergonhosa.

Posteriormente, dez anos após o retorno à democracia, através da Lei n 9.140/1995, o Estado brasileiro criou a Comissăo Especial sobre Mortos e Desaparecidos (CEMDP), com a finalidade de atuar na busca, investigaçâo, localizaçáo e identificaçáo das vítimas da ditadura. Através dessa lei as famílias dos desaparecidos obtiveram atestados de óbitos e pediram indenizaçóes. No entanto, embora tenha sido um marco importante para o estabelecimento de açóes reparadoras, a citada comissăo năo conseguiu obrigar o estado a esclarecer os delitos cometidos no período ditatorial.

Além dessas iniciativas é preciso ressaltar a atuaçăo dos movimentos sociais e organizaçôes de direitos humanos em diversas partes do território nacional, os quais desenvolveram importantes atividades, tais como investigaçōes, projetos de memória e de educaçăo. Por exemplo, em Săo Paulo sobressaem-se a Comissáo de Familiares de Mortos e Desaparecidos Políticos e o Comitê por Memória, Verdade e Justiça. Também nâo podemos deixar de mencionar que a participaçăo das novas geraçóes nessa luta foi e continua sendo fundamental para a continuidade da defesa dos direitos fundamentais aos opositores à brasileira e de seus familiares.

Verificamos que o trabalho de todos esses grupos contribuiu para a instalaçăo da Comissăo Nacional da Verdade (CNV), a qual foi oficializada em 18 de novembro de 2011 por meio da Lei $n^{0} 12528 / 2011$. Contudo, somente em 16 de maio de 2012, a CNV começou a funcionar com o objetivo de investigar e esclarecer as violaçôes de Direitos Humanos ocorridas entre 1946 e 1988. Durante a sua permanência, a Comissáo coletou 1.121 depoimentos, através de diversas audiências públicas ou privadas, investigou locais, instituiçôes e circunstâncias relacionadas às violaçôes de direitos humanos, e examinou documentos, arquivos e outras fontes de informaçóes sobre o período ditatorial.

No dia 10 de dezembro de 2014, a CNV entregou o seu relatório final, dividido em três volumes, contendo mais de 3000 mil páginas. Interessa-nos enfatizar que a Comissâo esclareceu as circunstâncias da morte de 434 pessoas reconhecidas como desaparecidas e mortas no regime autoritário. Também nomeou 377 pessoas como responsáveis direta, ou indiretamente, por crimes praticados na ditadura, como tortura e assassinato. Assim, acreditamos que esse documento pode ser visto como o reconhecimento oficial do Estado brasileiro de sua responsabilidade por crimes cometidos no governo de exceçấo, funcionando como um ato simbólico de promoçăo de justiça reparadora para as suas vítimas e familiares.

A Comissăo ainda apresentou 29 recomendaçōes, a fim de efetivar a Justiça de Transiçăo em nosso país e garantir a permanência de instituiçóes democráticas. Entre elas, sublinhamos o reconhecimento da responsabilidade das Forças Armadas nas violaçôes aos direitos humanos durante o regime autoritário e a continuidade da política de abertura dos arquivos da ditadura. Enquanto isso năo ocorrer, vários crimes que foram cometidos no período do terror náo serâo esclarecidos e os culpados nâo seráo julgados. Consideramos que essa problemática se deve ao fato de a lei da Anistia ser falha, 
conforme explicitou Pilla na epígrafe que inaugura esse tópico. Afinal, embora tenha proporcionado o retorno de exilados e libertado alguns presos políticos é eticamente inadmissível equiparar as vítimas aos torturadores e assassinos, deixando-os impunes.

Nesse sentido, Figueiredo (2017, p.26) sustenta que "No Brasil năo se cultiva a memória política porque a anistia significou amnésia, o país se recusa a enfrentar seu passado, a rever os crimes cometidos, a expor as atrocidades perpetradas por um regime de exceçăo." A crítica assinala que em 2010 a Ordem dos Advogados do Brasil (OAB) solicitou ao Supremo Tribunal Federal (STF) a revisâo da lei de Anistia. Embora a petiçăo năo tenha obtido sucesso, nesse ano o nosso país foi sentenciado pela Corte Interamericana de Direitos Humanos a investigar as atrocidades cometidas na ditadura. Explica que

Para a Corte, a lei de anistia năo é compatível com a Convençăo Americana sobre Direitos Humanos que foi assinada pelo Brasil. No entanto, para o STF, a Corte năo tem interferência sobre a legislaçâo interna. Assim, comparado com outros países do Cone Sul (Uruguai, Argentina e Chile), o Brasil continua avesso a uma revisăo de seu passado. (FIGUEIREDO, 2017, p.25)

O fragmento desvela como o nosso país está atrasado em relaçăo à investigaçăo e puniçâo dos crimes cometidos durante a ditadura brasileira devido a questionável lei da anistia. Acreditamos que os processos de redemocratizaçăo adotados nas naçóes do Cone Sul, marcados pela investigaçâo dos crimes contra a humanidade e pela condenaçăo de assassinos e torturadores, nos inspiram a continuar lutando pela memória, verdade e justiça no Brasil. Pensamos que nossa sociedade ainda precisa se debruçar sobre esse momento trágico de nossa história para poder superá-lo, bem como para que as desventuras ditatoriais nâo sejam repetidas. Como vimos na introduçâo, essa tarefa está sendo realizada de distintas maneiras por nossos escritores contemporâneos e a leitura dessas obras pode ser um caminho produtivo para reelaborarmos essa época de horror e, quiçá, implantarmos a desejada justiça às vítimas da ditadura e aos seus familiares.

\title{
NOTAS SOBRE AS INTERSECÇÕES ENTRE LITERATURA, HISTÓRIA E MEMÓRIA
}

\author{
"Graças a Deus fiz oito anos de análise para elaborar isso, senāo ficaria com uma \\ raiva muito grande. Consegui elaborar, controlar essa raiva. Tanto que escrevo o livro \\ sem marca de amargura." (PILLA, 2015, s. /p.)
}

Embora as relaçôes entre a literatura e a história sejam antigas, atualmente, elas se acentuaram. Em seu livro O romance histórico brasileiro contemporâneo (19752000), Antonio Roberto Esteves (2010, p.18) assinala que "A partir da segunda metade do século XX, é quase consenso generalizado que a história e a literatura têm algo em comum: ambas sâo constituídas de material discursivo, permeado pela organizaçâo subjetiva da realidade feita por cada falante, o que produz infinita proliferaçăo de discursos." Dessa forma, é possível aproximá-las por sua discursividade.

O crítico ressalta que a história está muito presente na literatura contemporânea de distintas maneiras, especialmente, na América Hispânica, mas também em nosso 
país. Aponta que sua presença pode ser identificada na forma clássica de romances históricos ou de novos romances históricos, em narrativas híbridas (biografias e biografias romanceadas), crônicas, autobiografias e até nas narrativas televisivas e cinematográficas de caráter histórico. Em sua opiniăo, "[...] como leitora privilegiada dos signos da história, a literatura é cerne de renovaçăo. [...] Essa é a melhor garantia da viabilidade de um futuro para a América Latina, nela incluída, evidentemente, o Brasil." (ESTEVES, 2010, p.25). Nessa ótica, os escritores têm a oportunidade de realizar produtivas releituras críticas da história de nosso continente em suas obras, contribuindo para a compreensâo de nosso passado e a construçấo de uma sociedade mais justa.

Por sua vez, na apresentaçăo da coletânea Ficçóes contemporâneas: história e memória, Marilene Weinhardt (2015, p.7) observa que "A leitura sistemática da produçáo ficcional que se mostra rentável da perspectiva do diálogo com a história demonstra que a recorrência do discurso de memórias como recurso ficcional vem se intensificando." Em síntese, há uma crescente conexāo entre os discursos da literatura, da história e da memória na contemporaneidade.

No artigo “Filhos da geraçăo de 1960/1970: herdeiros da memória, a crítica adverte que o uso de discursos de memórias como estratégia para construir o universo ficcional nâo é nenhuma novidade, visto que

Quem conta, rememora. Quando o passado é evocado - o que quer dizer criado, năo só por se tratar de ficçăo, mas porque náo é possível voltar ao passado, nem mesmo no empirismo - de tal sorte que o plano individual esteja inscrito nos eventos públicos (JAMESON, 2007, p.190), afetado pela experiência da coletividade, uma das opçóes rentáveis de abordagem é ler a obra buscando apreender como se realiza o diálogo da ficçăo com a história. (WEINHARDT, 2015, p.237)

Concordamos com essas afirmaçóes e consideramos que a confluência entre literatura, história e memória pode propiciar uma leitura significativa das ficçôes sobre as ditaduras latino-americanas. Além disso, essa tríade oportuniza que as memórias dos defensores da democracia sejam preservadas e que novas geraçôes conheçam essas histórias de diferentes pontos de vista, combatendo o esquecimento quase generalizado de nossa sociedade sobre esta época atroz. Sobre esse tema, Figueiredo (2017, pp.28-29) afirma que

Há esquecimento de duas ordens: o individual e o coletivo. 0 esquecimento individual se dá quando uma pessoa, após um trauma recalca o vivido que provocou o sofrimento, jogando-o no porăo do inconsciente; ao năo conseguir fazer o trabalho de luto, a pessoa produz sintomas, de maneira repetitiva. Para haver cura, é preciso relembrar, reviver o trauma através da palavra, ou seja, da narrativa, nas sessôes de psicanálise ou através da escrita. Já o esquecimento coletivo vem do desejo ou necessidade de um grupo social de querer esquecer ou denegar o acontecido.

Esse fragmento nos remete à epígrafe deste tópico, no qual Pilla expóe o seu processo de cura das violentas experiências sofridas durante as ditaduras argentina e brasileira, o qual passou pela psicanálise e pela construçăo de seu romance. Nessa declaraçăo, evidencia-se o papel da escrita como forma de reviver e reelaborar o trauma vivido pela autora gaúcha, o qual foi superado através de sua narrativa, pois conseguiu escrever suas memórias desse período de horror de uma maneira peculiar, abandonando a amargura que caracteriza muitas obras sobre os governos ditatoriais. Além disso, 
ao relembrar a sua trajetória, a autora colabora para combater o apagamento deste momento vergonhoso para nosso país.

Para Paul Ricouer (2007), os acontecimentos violentos que marcaram as histórias nacionais formam feridas que precisam ser curadas por meio do luto e do trabalho da memória. Dessa forma, infere-se que para superar o trauma é preciso recordar e, consequentemente, combater o esquecimento. 0 crítico ressalta que

[...] é no plano da memória coletiva, talvez mais ainda do que na memória individual, que a coincidência entre trabalho de luto e trabalho de lembrança adquire seu sentido pleno. $O$ fato de se tratar de feridas do amor próprio nacional justifica que se fale em objeto de amor perdido. É sempre com perdas que a memória ferida é obrigada a se confrontar. (RICOUER, 2007, p.92-93)

O excerto reforça a necessidade do trabalho memorialístico para superar os traumas individuais e, principalmente, os coletivos. Nessa perspectiva, Figueiredo (2017, p.29), esclarece que "Como se trata de uma história rasurada, a recuperaçâo do passado pela escrita (literária, jornalística ou mesmo historiográfica) vai juntar e rearrumar os dados do passado." A estudiosa compara essa reescrita com um pergaminho a ser decifrado, recomposto, ressignificado, pois

A literatura sobre a ditadura se constrói a partir desse palimpsesto e cumpre o papel de suplemento aos arquivos que, ainda quando abertos à populaçâo para consulta, săo áridos e de difícil leitura. Ao criar personagens, ao simular situaçôes, o escritor é capaz de levar o leitor a imaginar aquilo que foi efetivamente vivido por homens e mulheres. (FIGUEIREDO, 2017, p.29)

A citaçăo explicita a relevante funçâo arquivista da literatura na reconstruçâo das histórias sobre o período ditatorial, bem como a sua capacidade de conscientizar e humanizar os leitores que entram em contato com as ficçôes que abordam esta temática. Para a pesquisadora,

Aqueles que tentam hoje escrever sobre o passado da ditadura se apoiam, de um lado, nas lembranças pessoais e familiares, de outro lado, em informaçôes levantadas e já compiladas nos diferentes arquivos. Muitos familiares de mortos e desaparecidos fizeram suas buscas, contribuindo para esclarecer os fatos e desmontar as farsas. 0 trabalho de escavaçáo năo terminou e a quantidade de livros publicados, sobretudo desde 2010, comprova que o trabalho de elaboraçăo do trauma da ditadura continua. (FIGUEIREDO, 2017, p.30).

Observamos que esses elementos estăo presentes na ficçâo de Pilla, dado que ela parte de suas lembranças para denunciar os abusos cometidos pelos regimes ditatoriais no Cone Sul, conectando suas memórias pessoais com a memória coletiva. Aliás, em sua narrativa ela năo só reelabora o trauma que vivenciou, mas também clama por justiça aos que lutaram contra a repressăo. A seguir, examinaremos como a escritora aproximou os discursos da literatura, história e memória em Volto semana que vem.

\section{Uma longa semana de resistência...}

"Houve um amplo movimento contra a ditadura que envolveu o conjunto da sociedade brasileira. Basta lembrar o peso que teve o movimento artístico-cultural daqueles anos contra o regime. A resistência contra a censura e a truculência policial se 
expressou no teatro, na música, no cinema, na imprensa alternativa, nos festivais

artísticos reunindo milhares de espectadores país afora. Os militantes organizados

foram parte disso, talvez o seu flanco mais frágil, o mais suscetível à repressāo."

(PILLA, 2015, s./p.)

No artigo "50 anos da ditadura no Brasil: questóes feministas e de gênero", Ana Maria Colling (2015, p.378) afirma que "A história da repressăo durante a ditadura militar e assim como a oposiçăo a ela é uma história masculina, basta que olhemos a literatura existente sobre o período." Estamos de acordo com esta declaraçăo, mas é preciso ressaltar que a invisibilidade das mulheres nessa época năo é exclusividade de nosso país, conforme assinala Margareth Rago na apresentaçăo do dossiê "Memórias submissas", publicado na revista Labrys em 2009. Para a estudiosa,

Năo é demais lembrar, mais uma vez, como as mulheres estiveram presentes nas lutas de resistência às ditaduras militares implantadas na América Latina, nos anos setenta e, paradoxalmente, como têm estado ausentes, com algumas exceçóes, nos textos históricos e nas produçôes biográficas e autobiográficas, em que se narram os trágicos acontecimentos que marcam dolorosamente esse período. (RAGO, 2009, s./p.)

Diante da problemática exposta neste excerto, consideramos que é importante para o exercício de nosso dever de memória escutar as vozes femininas de resistência e conhecer suas histórias, preservando-as. Assim, no presente trabalho, examinaremos como as mulheres que combateram as ditaduras implantadas no Cone Sul na década de 1970 foram representadas no romance Volto a semana que vem, de Maria Regina Jacob Pilla, uma escritora, tradutora e jornalista gaúcha. Na década de 1960, ela ingressou no Partido Comunista Brasileiro, e depois na Dissidência no Rio Grande do Sul. Também participou da formaçăo do Partido Operário Comunista (POC). Após viver um período na clandestinidade em Săo Paulo, em 1970 se exilou na França e integrou-se à IV Internacional. Dali mudou-se para a Argentina a fim de militar no Partido Revolucionario de los Trabajadores (PRT). Em 1975 foi presa e torturada em Buenos Aires, passando pelas prisōes de Olmos e de Villa Devoto. Por ser estrangeira foi expulsa do país em 1978 e conseguiu asilo político na França, onde atuou nos movimentos feministas. Somente em 1992 retornou definitivamente ao Brasil.

Em Volto semana que vem (2015), a autora ficcionaliza sua trajetória, transitando por sua infância e juventude. Paralelamente, recupera acontecimentos importantes da história latino-americana ocorridos de 1950 a 2011. Sobre sua motivaçăo para a elaboraçăo dessa obra, explica que

Há anos, tinha vontade de escrever um livro, de botar no papel tudo aquilo, que, apesar de ter feito análise, continua me incomodando. Escrever o livro foi como me livrar de um problema, me livrar de um período da minha vida que foi bacana, no qual aprendi muita coisa, mas também enfrentei coisas bem difíceis. Deixei para escrever as partes ruins todas juntas. Foi bem difícil. Era uma coisa sofrida, que vinha de dentro. (PILLA, 2015, s./p.)

A citaçâo indica que o processo catártico de escrita de sua narrativa, uma estratégia para superar o trauma causado pelas últimas ditaduras cívico-militares no Brasil e na Argentina. Entretanto, ela esclarece que "Năo sou vítima, eu escolhi a militância. Năo sabia tudo que aconteceria, mas sabia que náo ia ser fácil, que tinha morte, tortura. É idiota e desonesto quem fala que năo sabia. Foi uma escolha minha que assumo." (PILlA, 2015, s. /p.). Nessa declaraçăo, explicita o seu compromisso com a luta pela 
democracia, assumindo o papel de militante consciente e recusando o vitimismo. Essa atitude resiliente permeia o seu relato, como discutiremos neste tópico.

O romance de Pilla está dividido em 56 capítulos curtos, os quais apresentam datas e ficcionalizam episódios de sua vida de forma fragmentada. Dessa maneira, por sua estrutura, podemos filiar essa obra ao gênero diário. Porém, apesar de suas similitudes com esse tipo de texto, cabe ressaltar que as datas estâo embaralhadas e, portanto, há uma desordem cronológica. Inferimos que esse vaivém funciona como uma simulaçâo dos movimentos da memória, um fator que reforça seu teor memorialístico. Encontramos algumas fotos da escritora na capa, nas páginas iniciais e no final, ao lado de sua autobiografia, sendo que em duas também aparecem outras mulheres. Na última página do livro somos informados que estas imagens fazem parte do acervo da autora, exceto a da capa, creditada a Jean-Luc Daniel. Assim, geram-se dúvidas sobre a figura presente na cobertura do livro, pois pode năo ser uma representaçăo da escritora, tanto pelo crédito quanto pelo fato de a imagem estar borrada. Contudo, entendemos que ela simboliza a partida da protagonista de Volto a semana que vem, uma vez que mostra uma mulher ao lado de um carro com a porta aberta, dialogando com o título e o tema da ficção.

Interessa-nos assinalar que a tradicional apresentaçâo de autores, comumente feita em terceira pessoa, é realizada por Maria Pilla, sinalizando o predomínio de sua voz na narrativa e problematizando os limites entre realidade e ficçăo, bem como reforçando o seu teor autobiográfico. Porém, na orelha da obra surge outra voz: a do escritor e pesquisador José Almino. Em sua apreciaçâo do romance, ressalta que "A matéria considerável aqui é a memória, matéria tratada com o cuidado, a minúcia e o sentido da construçăo literária. Talvez por isso, apesar do sofrimento por ele evocado, este nâo é um livro triste. E em algum lugar, a autora sugere, novamente com a devida ironia: 'Fomos quase felizes'." (ALMINO apud PILLA, 2015, s./p.). O fragmento explicita algumas características da ficçâo da escritora gaúcha: a relaçăo entre memória e literatura, a qual examinaremos em nosso trabalho, bem como a sua conexăo com a história latino-americana, desconsiderada pelo crítico.

$O$ relato é feito, geralmente, em primeira pessoa por uma narradora personagem que apresenta biografemas da autora, mas há momentos em que a história é contada por um narrador onisciente. Devido à sua estrutura, aos paratextos e a essas marcas podemos inserir a obra de Pilla no rol da autoficçáo, definida como "[...] um romance autobiográfico pós-moderno, com formatos inovadores: sâo narrativas descentradas, fragmentadas, com sujeitos instáveis que dizem "eu" sem que se saiba exatamente a qual instância enunciativa ele corresponde." (FIGUEIREDO, 2013, p.61). Embora essa interpretaçáo seja viável, năo iremos desenvolvê-la em nosso estudo, pois objetivamos investigar como a literatura, a história e a memória se conectam na ficçâo da autora gaúcha, ressignificando a participaçâo das mulheres na luta contra as ditaduras latino-americanas.

É notória a circularidade da narrativa, dado que a açâo é iniciada e finalizada com histórias familiares. O primeiro capítulo intitula-se "1953| O quadro de Stanislau" e somos informados de que "É um quadro estranho, feito em duas partes distintas: a madeira do fundo está coberta com uma sorte de veludo grená e sobre ele há um pequeno retângulo de metal com uma imagem de Cristo na cruz em cores densas e escuras." (PILLA, 2015, p. 7). Essa figura insinua que estaremos diante de um relato 
de sofrimento, devido à presença do cristo crucificado. Entendemos que essa imagem funciona como desencadeadora das memórias da protagonista, uma vez que, a seguir, ela começa a descrever a biografía de seu avô materno, um ucraniano que mesmo sendo um cristăo novo precisou fugir dos pogroms russos e veio para a América, trazendo o quadro em sua travessia.

Já o último capítulo do livro, "1984|Veneza, Cidreira" é destinado ao avô paterno. Nesse apartado, ele conta para a neta que na ilha de Lido viveu um comerciante que tinha o sobrenome Pilla e que possuía uma casa enorme, mas ela registra que "Em Veneza, na praia do Lido, ninguém mais se lembra do tal vendedor de vinho." (PILLA, 2016, p. 91). Desse modo, o início e o final da narrativa aproximam os dois troncos de sua família, ressaltando a importância da preservaçăo da memória familiar e de sua relaçâo com a memória coletiva, uma vez que ao manter viva a história de seus ancestrais, conserva o seu passado e conecta-o com conhecidos eventos históricos.

Nesse sentido, observamos que a trajetória de seu avô materno está conectada com acontecimentos da história europeia e americana, dado que ele foi perseguido em seu país por sua origem judia e para sobreviver precisou emigrar para nosso continente, tal como vários judeus e inúmeros europeus fizeram no século XX. Consideramos significativo que esse episódio esteja situado em 1984, dado que foi o ano do grande comício popular organizado pelo movimento "Diretas Já", o qual contribuiu para o início da redemocratizaçấo. Portanto, a obra termina com uma alusăo ao fim da ditadura e o alerta de que é necessário conhecer e recordar nosso passado para que nâo seja esquecido.

Interessa-nos assinalar que a infância da protagonista é marcada pelo contato com a arte. Ela declara que sua mâe lhe instigou o gosto pelo cinema e que a música ocupava um lugar especial em sua casa. Também rememora a sua escola, a convivência familiar e os vizinhos. De forma aparentemente casual, relembra que um deles era militar e o outro um general aposentado, o qual é descrito como um "[...] homem cioso da moral e dos bons costumes, nunca deixou de passar para o nosso lado da cerca um feixe de varas de marmelo, utilizadas lá em casa para completar nossa educaçấo." (PILLA, 2015, p.89). Esse fragmento indica que a violência estava desde cedo ao seu redor. Além disso, relata um incidente que ocorreu no quintal do general quando um coqueiro foi incendiado e as crianças comemoraram o acontecimento de maneira efusiva, mas depois foram punidas pelos pais. Segundo a narradora, "Naquela noite as varas de marmelo do general prepararam para a vida as crianças da nossa rua." (PILLA, 2015, p.90). Pensamos que essa cena é bastante significativa, pois mostra a precoce experiência da protagonista com o autoritarismo e indicia sua "preparaçăo para a vida", isto é, sua resistência à dor.

A história nacional também permeia sua infância. Por exemplo, no apartado "1954|24 de agosto", conta-se a morte de Getúlio Vargas e os distúrbios que ocorreram em Porto Alegre nesse momento. Esse fato impactou sua família, porque o seu pai trabalhava no prédio em que funcionava o Partido Libertador, contrário ao getulismo. Na ocasiâo, o edifício foi incendiado e ele precisou descer três andares em chamas, mas conseguiu chegar até sua casa, apesar dos ferimentos. A protagonista informa que "Naqueles dias dos meus oito anos, Getúlio enveredou para a eternidade enfrascado num pijama listado." (PILLA, 2015, p.19), desvelando como o episódio permaneceu registrado em sua memória, mesclando a experiência individual de seu pai com a morte do ex-presidente, um acontecimento marcante de nosso passado. 
Em relaçấo à sua adolescência, destaca-se o período que estudou nos Estados Unidos (1963-1964), a fim de concluir o Ensino Médio, abordado em dois capítulos. O primeiro intitula-se "1963| Open house. Walnut Hills Hight School" e nele a personagem descreve a primeira festa em que participou quando chegou ao exterior, explicando que "Havia algumas regras, mas ali, muito antes do maio francês de 1968, valia o "proibido proibir", ainda que do jeito puritano deles." (PILLA, 2015, p. 27). Por sua vez, o segundo apartado, "1963| Marcha pelos Direitos Civis", recria o momento em que assistiu pela televisăo à transmissáo do conhecido discurso de Martin Luther King, juntamente com a família que a hospedou em Cincinnati. Considera que a partir desse evento "[...] outro país começava a nascer e surgiam as primeiras notas de minha politizaçăo." (PILLA, 2015, p.66). Assim, a citaçấo registra o início de sua conscientizaçăo. Ademais, esses fragmentos também aludem a dois importantes episódios da história mundial, o Maio de 1968, protagonizado por jovens estudantes franceses que lutavam por mudanças em seu país, e a Marcha pelos Direitos Civis, a qual reivindicava o fim da segregaçấo racial nos Estados Unidos. Portanto, a narradora aproxima sua vivência particular com a história internacional.

Já a militância da protagonista é ficcionalizada em alguns trechos que abarcam os anos de 1967 a 1970. Em “1967 | Centro Acadêmico, Faculdade de Filosofia. Marcâo. Che" relata o convite de um colega para participar de uma reuniăo do Partidăo quando iniciou o seu curso de Jornalismo na Universidade Federal do Rio Grande do Sul. A partir desse momento ela começou a participar de um grupo que questionava a autoridade de históricos líderes comunistas. Explica que "Chamavam-nos depreciativamente "os jovens". Seguíamos em frente passando por cima de tudo: năo queríamos uma vida como a deles, nossos pais. Queríamos tudo, e tudo em excesso. A vida, o amor, a política, a ventura, o mundo. Um mundo que fosse bem melhor do que aquele." (PILLA, 2015, p.32). O excerto desvela os ideais de uma parcela significativa da juventude dos anos de 1960-1970 que desejava melhorar a sociedade e por isso participava de movimentos políticos de esquerda. Entretanto, essa ideologia era vista como uma ameaça para o regime autoritário e foi duramente combatida, como verificamos nessa ficçăo.

No capítulo "1970| Volto semana que vem", o qual nomeia o livro, a protagonista rememora dois episódios históricos importantes, nos informando que "Costa e Silva assinara o AI-5. O congresso clandestino da UNE, Uniăo Nacional dos Estudantes, em Ibiúna, caíra." (PILLA, 2015, p.19). O primeiro evento refere-se à promulgaçăo do Ato Institucional número 5 em 1968, que vigorou por 10 anos e deu poder aos governantes para realizar puniçôes arbitrárias aos opositores da ditadura. Entre as restriçôes de liberdade, foram proibidas as reuniōes estudantis e por isso a UNE tentou realizar o seu encontro clandestinamente no interior de Sáo Paulo que culminou com a prisăo de mais de 700 estudantes. Nesse contexto, a personagem sente-se ameaçada e precisa sair de sua cidade. Observamos que novamente a sua história está entrelaçada com a de nosso país. A despedida de seus familiares é descrita brevemente:

O pai vestia um pijama claro, estava em pé na cozinha. Eu deveria sair por uns dias. Quis exagerar para náo assustar, se demorasse mais que o previsto. Uma semana e estaria de volta. Poxa, tanto tempo assim? É. Mando notícias.

Mais de dez anos se passaram até eu voltar àquela cozinha. (PILLA, 2015, p. 18) 
A citaçăo esclarece o título do livro, uma referência à entrada da personagem na clandestinidade e, posteriormente, no exílio, postergando por uma década o seu regresso à sua casa devido ao acirramento da perseguiçấo aos opositores da ditadura. Cabe frisar que o seu retorno só foi possível devido à Lei da Anistia, promulgada em 1979. Quando deixa sua casa, a protagonista viaja para Săo Paulo e depois vai para Paris. Sua partida para a França é marcada pela apreensáo de ser presa. Por isso, mesmo quando estava no aviăo "Năo conseguia respirar, a ameaça estava ali, suspensa no ar. Mesmo no meio do oceano, horas mais tarde, ela náo ia embora. E demorou a passar. Foram mais de vinte anos de exílio e oito de divâ." (PILLA, 2015, p.19). O fragmento enfatiza o trauma que a protagonista sofreu por medo de vivenciar as atrocidades do sistema repressivo brasileiro, o qual precisou ser reelaborado pela psicanálise.

Para explicitar a violência desmedida do governo ditatorial, a narradora relembra a morte do político e escritor Carlos Marighella (1911-1969), um dos principais líderes da resistência armada à ditadura assassinado em uma emboscada, ocorrida um ano antes de sua partida para o exílio. Embora relate um acontecimento triste, finaliza-o de forma provocativa: "Carlos Marighella, dizem, começou suas andanças carcerárias por causa de um poema. Um poema certamente debochado, que năo agradava as pessoas de bem. E muito menos os quepes que assolavam o país." (PILLA, 2015, p.21) Trata-se do poema "Liberdade", escrito por Marighella em 1932, motivo de sua primeira prisấo. Pensamos que a citaçấo indicia a força da literatura no processo de conscientizaçăo e de resistência à opressăo.

A importância da leitura literária também é mencionada em "1967|Centro Acadêmico, Faculdade de Filosofia. Marcáo. Che." Nessa parte, além de descrever o seu contato com o movimento estudantil e a política partidária, conforme assinalamos anteriormente, a protagonista também relata que "Pela máo de um jovem jornalista do Bom Fim, Marcos Faerman, o real maravilhoso da literatura entrava em nossas conversas com os mesmos direitos que Ho Chi Minh e a guerra do Vietná." (PILLA, 2015, p.32). Assim, a literatura adquire o mesmo valor que a política para a protagonista, mostrando a relevância da cultura como elemento de resistência à ditadura. Interessa-nos registrar que tanto as mençóes ao citado poema de Marighella quanto à vertente do realismo maravilhoso săo feitas de forma alusiva, sem explicitar os títulos das obras, instigando o leitor a buscar estas informaçóes.

No capítulo "1971 Marcăo do Versus", entramos em contato com outra forma de combate ao autoritarismo: o trabalho jornalístico. Desse modo, somos informados de que Faerman

Fez o Versus, um jornal "de ideias e de política", dizia. Pioneiro da imprensa alternativa, o Versus era a morada da melhor literatura do continente, do melhor cinema, dos melhores jornalistas e escritores. Foi eco para o jornalista argentino Rodolfo Walsh, desaparecido em 1977 depois de escrever uma carta à Junta Militar do general Videla. Marcáo e Walsh fizeram, no continente, um jornalismo que escreveu as páginas da história quando ainda estavam acontecendo. Năo se camuflavam atrás de uma objetividade falsa, nem fugiam de suas responsabilidades como intelectuais de seu tempo. (PILLA, 2015, p.40)

A citaçâo nâo destaca apenas o relevante papel da arte na resistência cultural à ditadura, mas também exalta a escrita jornalística comprometida, realizada pelo brasileiro Marcos Faerman (1943-1999) e pelo argentino Rodolfo Walsh (1927-1977), os quais 
seguiram denunciando os governos ditatoriais, apesar da censura e das ameaças às suas vidas. A protagonista também expressa sua admiraçăo por assumirem o papel de intelectuais comprometidos com a defesa da democracia. Consideramos que, ao recuperar as suas histórias, Pilla filia-se à mesma linhagem escritural de Faerman e Walsh, visto que em sua ficçăo identificamos várias denúncias de arbitrariedades cometidas nos regimes de exceçăo latino-americanos, sobre as quais nos debruçaremos a seguir.

Uma delas encontra-se em "1971| Operaçăo Bandeirantes, Săo Paulo", um relato que gira em torno do drama de dona Iracema que recebe a notícia de que o seu filho se suicidara debaixo de um caminhăo. A măe năo acredita nessa explicaçăo, dado que recentemente ele havia sido levado de casa por policiais. A narradora declara que "[...] a partir daquele dia dona Iracema foi uma măe brasileira em busca da justiça que tarda. Nunca entendeu como é possível um jovem de vinte e três anos ser morto por causa de seus ideais." (PILLA, 2015, p.22). Esse trecho recupera um frequente procedimento praticado durante os governos autoritários que registrava oficialmente o assassinato de muitos militantes como suicídios. Também questiona a razăo da morte do filho de dona Iracema, pois, tal como a personagem, pensamos que é inadmissível que um ser humano seja morto por sua ideologia. Além disso, relaciona essa história particular com a de muitas máes que lutam por justiça para os seus filhos que foram assassinados durante governos autoritários năo só no Brasil, mas em outros países da América Latina. Pensamos, ainda, que o título do capítulo é bastante significativo, visto que se refere à OBAN, uma organizaçâo paramilitar brasileira que integrava as forças armadas e policiais para combater "os subversivos", financiada por empresários paulistas. Dessa maneira, indiretamente, desvela-se a participaçăo da sociedade civil no sistema repressivo de nosso país.

Diante dessas barbáries a protagonista decide voltar a militar na América Latina e viaja para a Argentina, através do Chile, descrevendo seu percurso com ironia: "Certamente um caminho mais longo e uma marcha à ré na história: saía de um país com um governo civil recém-eleito para outro em plena ditadura militar." (PILLA, 2015, p.14). A citaçấo refere-se à eleiçăo do presidente chileno Salvador Allende (19081973) em 1970, o qual foi deposto por um golpe de estado coordenado por seu chefe das Forças Armadas em 1973, e ao golpe militar argentino de 1966.

A seguir, o contexto histórico argentino é reconstruído e a tentativa de Alejandro Lanusse de restabelecer a democracia em 1971 é ironizada, bem como o Gran Acuerdo Nacional que estava sendo costurado para o retorno de Juan Domingos Perón (18951974). Vale a pena relembrar que Perón governou a Argentina de 1946 a 1955, renunciando ao seu mandato devido ao levante militar iniciado em Córdoba. Ele exilou-se na Espanha, governada pelo fascista Francisco Franco, depois de passar pelo Paraguai e pela República Dominicana quando esses países tiveram ditadores no poder. Na ficçăo, a narradora revela que "Em Madri, Perón recebia mensageiros. Negociaçôes sem fim tramavam um novo país, e ele, o líder, recebia a todos, exibindo nos olhos a habilidade cruel dos negociadores. Tempos depois, numa tarde fria e cinzenta de inverno, o general Juan Domingos Perón pisaria nas terras úmidas da pátria." (PILLA, 2015, p.14). Assim, vários episódios da história latino-americana vêm à tona de forma alusiva, interligando-se e evidenciando a ostensiva presença de regimes autoritários em nosso continente no século passado. 
Historicamente, Perón retornou para a Argentina em 1973, sendo reeleito para presidir o país. Porém, faleceu no ano seguinte e foi sucedido por sua esposa, María Estela Martínez de Perón, conhecida como Isabelita. Ela governou até março de 1976 quando foi destituída pela última ditadura argentina, orquestrada pelas Forças Armadas e denominada de "Processo de Reorganizaçăo Nacional". O período de seu mandato é ficcionalizado por Pilla, conforme examinamos em seguida.

No capítulo "1974| O ano de todos os perigos", entramos em contato com os assassinatos de Rodolfo Ortega Peña (1936-1974), um advogado, militante e deputado peronista, e de Sílvio Frondizi (1907-1974), advogado e professor universitário, irmăo de um ex-presidente da Argentina. Depois de descrever brevemente suas execuçóes, a narradora informa que "Trinta e cinco anos depois, em 2009, Rodolfo Almirón Sena, um dos chefes da organizaçâo paramilitar Alianza Anticomunista Argentina, a triple A, sentou-se no banco dos réus." (PILLA, 2015, p.70). Dessa forma, o episódio finaliza com uma mençăo ao julgamento de um dos chefes da AAA, a qual agia em conjunto com a Aliança Anticomunista Americana (Colômbia), como parte da Operaçăo Condor, um pacto entre os governos da América do Sul com a CIA dos Estados Unidos para combater os opositores dos regimes ditatoriais em nosso continente.

Segundo o relatório da CONADEP (1983), a AAA executou mais de 1222 pessoas e isso explica a atitude da protagonista no momento de sua prisăo em 1975, pois declara que "[...] foi um alívio ver o automóvel da polícia de Buenos Aires com os uniformes azuis-escuros dos policiais. Năo parecia ser um sequestro dos paramilitares do AAA. Tempos ruins aqueles em que ser preso pela polícia era o que de melhor podia acontecer a um militante em Buenos Aires." (PILLA, 2015, p.34-35). Assim, por meio da ironia, explicita-se o poder ilimitado dessa organizaçăo paramilitar que iniciou suas açôes no mandato de Isabelita e a consolaçâo de ter sido presa e năo "desaparecida".

Em “1975, 1978| Operaçăo Condor, Gallego, Petiza”, conhecemos um casal que vive na clandestinidade, uma vez que "[...] eram procurados pela polícia e tinham o rosto impresso em cartazes espalhados pela cidade. Năo podiam ter uma vida como a de todo mundo." (PILLA, 2015, p.49). Há poucas informaçôes sobre os personagens, mas o título do fragmento é muito sugestivo, dado que nos remete à mencionada aliança entre os governos dos países do Cone Sul e os EUA. A violência desse grupo é evidenciada no momento da prisăo do casal, o qual, após entregar a filha para um vizinho, é metralhado. Ademais de matá-los, querem eliminar seus vestígios, visto que "Duas patrolas invadiram o terreno, revirando a terra e os pertences da família. Nâo queriam deixar rastro daquela gente." (PILLA, 2015, p.50). Inferimos que esse episódio denuncia a crueldade da Operaçăo Condor e a tentativa de apagamento das histórias de suas vítimas, sintetizada através da morte física e simbólica dos personagens Gallego e Petiza, os quais nâo têm nome no relato, sendo mencionados por seus apelidos.

Na prisăo, a narradora conhece Emilia, uma militante uruguaia do Movimento de Liberación Nacional Tupamaros, estudante de medicina. Explica que ela "Foi presa em Buenos Aires e nâo entrou na lista dos uruguaios que foram jogados vivos de aviôes no rio da Prata." (PILLA, 2015, p.42). Além de escapar dos chamados voos da morte, também participou da histórica fuga de 38 presas uruguaias que foram resgatadas pelo referido movimento em 1971. É importante registrar que ela conseguiu sobreviver porque teve ajuda de um casal desconhecido. 
Também somos apresentados à Cachita, a qual foi detida por năo denunciar o paradeiro de seu filho, um militante da organizaçâo peronista Montoneros. A narradora registra que quando estava sendo transportada para o cárcere, "No caminho, pararam para encenar o fuzilamento de Cachita. Depois ela seguiu para a prisâo de Olmos." (PILLA, 2015, p. 12). A citaçấo demarca o absurdo nível de desumanidade do regime de exceçăo, pois o ato descrito era uma das torturas psicológicas que os repressores utilizavam com frequência durante a época do terrorismo do estado para amedrontar os presos políticos.

Outra história que vem à tona na ficçâo é a de Júlia, militante do Ejército Revolucionario del Pueblo, cujo companheiro foi assassinado por um policial em uma operaçăo realizada no interior de um ônibus. Ela ficou traumatizada porque "[...] năo enterrara seu morto, que retornava de vez em quando." (PILLA, 2015, p.15). Curiosamente, a narradora havia conhecido este episódio através de uma notícia publicada em um jornal, lido quando chegou à Argentina "[...] sem imaginar como minha vida estaria soldada aos personagens dessa história. Muitos laços se criariam entre nós, dos da militância aos afetivos." (PILLA, 2015, p.15). No relato, a protagonista reencontra a colega de cárcere durante o seu exílio na França e na Argentina em 2010 quando visitam o Centro clandestino de detençáo Atlético, momentos em que recordam seu passado traumático. O lugar é descrito como desolado e Júlia se emociona porque

\footnotetext{
Dos seus três irmăos ainda desaparecidos, dois, Eduardo e Ana Maria, haviam estado naquele lugar, o Clube Atlético, um dos campos de confinamento dos desaparecidos. O que víamos ali era uma escavaçáo de tipo arqueológico, toda ela cercada, a terra cinza-escura revirada para mostrar as celas, os banheiros, as salas de tortura. (PILLA, 2015, p.13)
}

Trata-se de um lugar de memória que objetiva preservar as histórias de todos os que estiveram presos ali. Entendemos que é significativo que as personagens realizem a visita juntas, evidenciando a permanência dos laços que construíram durante o encarceramento. Aliás, a narradora registra que "A maneira atabalhoada como o sistema repressor lidou com as presas perigosas que nós éramos deu-nos o grande benefício da convivência diária." (PILLA, 2015, p.23). Por meio dessa declaraçăo, se ironiza a classificaçâo das detentas políticas como perigosas, sinalizando que a atitude do sistema de isolá-las, paradoxalmente, aproximou-as. No relato, a "periculosidade" das mulheres que combateram os regimes ditatoriais é desconstruída tanto por meio da apresentaçâo de suas histórias quanto pela descriçăo de seu cotidiano na prisăo.

Na ficçâo, o cárcere é representado como um espaço de resistência e de solidariedade, embora as arbitrariedades do sistema também sejam registradas. Um exemplo de tenacidade é registrado no episódio dos uniformes, pois as presas políticas criam diferentes artimanhas para evitar usá-los. Já a solidariedade pode ser identificada na divisăo do trabalho, uma vez que para conseguir dinheiro fabricavam artesanatos com o miolo de páo e dividiam os ganhos e as demais tarefas. Também organizavam "sessóes de cinema" em que cada uma narrava um filme a que havia assistido e promoviam outras açôes culturais. Além disso, nos finais de semana havia atividades de lazer que "Do teatro aos espetáculos musicais, dos cassinos aos filmes da Metro e aos desfiles dos blocos carnavalescos, os shows levavam o conjunto das presas à grande cela transformada em auditório." (PILLA, 2015, p.41). Dessa forma, por meio da arte, conseguiram preservar sua humanidade ainda que vivenciassem momentos de horrores. 
A resistência cultural também pode ser identificada nos intertextos presentes no relato. Um deles aparece no capítulo "1976| Miguel Hernández, poeta de España", no qual insinua-se a importância da leitura para a manutençăo da esperança, representada pela rememoraçâo do poema "Nanas de la cebolla", do escritor espanhol Miguel Hernández (1910-1942), preso no início da guerra civil espanhola. O poema foi escrito em 1939 e musicalizado por Joan Manuel Serrat em 1972. No romance, a protagonista contextualiza o surgimento desse texto poético, explicando que ele foi escrito para a mulher de Hernández que só tinha páo e cebolas para alimentar o seu filho. Segundo a narradora, "Com o leite dessas cebolas de Espanha, nós, reféns da ditadura argentina, também aprendemos a temperar nossa espera." (PILLA, 2015, p. 23). Nesse sentido, o poema-cançâo ajudou-a a resistir ao cárcere, indiciando que a personagem se identificou com os versos do poeta espanhol. Diferentemente da alusăo ao poema "Liberdade" de Mariguella, o qual aparece no relato de maneira indireta, o de Hernández é reproduzido na narrativa de forma parcial. Assim, evidencia-se o papel de leitora da escritora gaúcha que ficcionaliza sua memória literária.

Como a protagonista era estrangeira, foi expulsa do país quase dois anos depois de ter sido privada de sua liberdade. $\mathrm{O}$ episódio de sua extradiçâo é descrito da seguinte maneira:

Na manhá seguinte, a Polícia Federal de Buenos Aires se livrou, num voo da Luthansa, de três presos estrangeiros expulsos do país: Paulo, eu e um paraguaio. Fomos entregues algemados ao comandante do aviăo diante dos passageiros. Quando o aviăo embicou para o espaço, ganhamos dos funcionários cervejas alemás e coloridos canapês de boas vindas. (PILLA, 2015, p.89).

Percebemos a ironia da narradora ao demarcar que os policiais argentinos "se livraram" dos presos políticos, dado que oficialmente os três estavam sendo libertados. Também informa que apesar da humilhaçăo de serem vistos algemados pelos passageiros, foram bem recebidos pelos tripulantes do aviăo. Acreditamos que esta partida rumo ao exílio e, portanto, à vida, contrasta com a denúncia dos voos da morte, exposta anteriormente e retomada em outros capítulos que serăo analisados a seguir.

Em "2011| Rodolfo Walsh, um argentino na Patagônia", aparecem fragmentos da "Carta abierta de un escritor a la Junta Militar" que o jornalista distribuiu aos jornais locais e correspondentes estrangeiros quando esta completava um ano de funcionamento. Os dois primeiros parágrafos da missiva săo reproduzidos no relato, nos quais Walsh justifica a circulaçăo de seu texto de forma clandestina devido à censura imposta à imprensa e ao assassinato de sua filha durante um combate com os repressores. Explica que "O primeiro aniversário dessa Junta militar me levou a fazer um balanço da açáo governamental baseado em documentos e discursos oficiais, onde o que vocês chamam de acertos săo erros, o que reconhecem como erros e o que omitem săo calamidades." (WALSH apud PILLA, 2015, p.71). Notamos que o excerto faz uma crítica contundente à ditadura argentina, desconstruindo seu discurso oficial.

Historicamente, essa missiva motivou o sequestro do escritor e a sua morte que "[...] ainda está cercada de mistério: 1977, o ano em que morreu, já era uma época sem sobreviventes que poderiam restabelecer os fatos." (PILLA, 2015, p.72). No capítulo "1976-77| Presos jogados de aviōes", surge a confissăo do oficial da marinha argentina Adolfo Scilingo de ter participado dos voos da morte, nos quais os presos políticos eram 
drogados e jogados no mar, sendo condenado à prisăo perpétua. Estes crimes haviam sido denunciados pelo jornalista argentino na referida carta e reaparecem no romance:

Entre 1500 e 3000 pessoas foram secretamente massacradas depois que vocês proibiram toda e qualquer informaçáo sobre a descoberta de cadáveres que em alguns casos, apesar da proibiçăo, transcenderam por afetar outros países, por sua magnitude genocida ou pelo espanto provocado em suas próprias fileiras. Vinte e cinco corpos mutilados apareceram entre março e outubro de 1976 nas costas uruguaias, restos talvez dos carregamentos dos torturados mortos na Escola de Mecânica da Armada e escondidos no rio da Prata em navios dessa arma. (WALSH apud PILLA, 2016, p.73)

A citaçấo evidencia a censura do regime de exceçâo e sua crueldade ao torturar, assassinar e jogar no mar os seus opositores. Acreditamos que ao interligar as denúncias do escritor argentino sobre os voos da morte, o seu assassinato e a condenaçấo de um dos envolvidos nesse delito, a autora ressignifica o trabalho feito por Walsh, mostrando que sua luta valeu a pena, pois a justiça, mesmo que tardia, foi feita. Entendemos que a longa semana de mais de 10 anos que a protagonista passou longe de casa pode ser vista como uma alegoria para descrever a sua militância contra as ditaduras brasileira e argentina. Nesta batalha, ela foi vitoriosa, visto que o seu voo nâo foi em direçấo à morte, mas à vida, mesmo que no exílio. Assim, ela conseguiu exercer o seu dever de memória e registrar as histórias de várias mulheres e homens que lutaram contra os governos ditatoriais no Cone Sul.

Pensamos que o diálogo intertextual com as obras de Walsh e de Hernández, bem como a alusăo ao poema "Liberdade" de Marighella sinalizam o papel da literatura no combate a desumanizaçăo e o autoritarismo. Afinal, na narrativa sua presença contribuiu para manter viva a humanidade e a esperança das personagens que foram encarceradas por lutar contra o terrorismo de estado em nosso continente, as quais eram o elo mais fraco na cadeia de oposiçăo aos governos ditatoriais, conforme exposto na epígrafe do presente tópico. Segundo Samouyault (2008, p.47), "A literatura se escreve com a lembrança daquilo que é, daquilo que foi. Ela a exprime, movimentando sua memória e a inscrevendo nos textos por meio de um certo número de procedimentos de retomadas, de lembranças e de re-escrituras, cujo trabalho faz aparecer o intertexto." Nessa perspectiva, a ficçáo de Pilla dialoga com obras de autores que se mostraram comprometidos com a luta pela democracia, formando uma "biblioteca da literatura de resistência", categoria em que podemos inserir Volto a semana que vem.

\section{PALAVRAS (QUASE) FINAIS}

"É o máximo, pois um de seus objetivos foi mostrar o que era a ditadura neste
país. Mas o que mais gostei na anistia foi terem me pedido desculpa pelo que
tinha acontecido." (PILLA, 2015, s./p.)

Em Volto a semana que vem, Pilla tece um relato autobiográfico, marcado pela brevidade e alusăo, bem como pela falta de linearidade e de cronologia. Desse modo, o leitor é provocado a reconstruir os acontecimentos históricos ficcionalizados e encontrar as obras literárias citadas. Por isso, em nosso estudo sentimos necessidade de 
organizar a apresentaçăo dos capítulos de forma cronológica, contextualizar os fragmentos selecionados e examinar mais detidamente o seu diálogo com outros textos que denominamos de "biblioteca da resistência". Pensamos que estes procedimentos adotados pela autora imitam os movimentos da memória, aproximando-a da literatura e da história.

No capítulo "2010| O centro clandestino de detençăo Atlético", a narradora descreve a visita de Júlia a um dos locais que eram utilizados para confinar os presos políticos na Argentina, transformado hoje em um espaço de memória. Ali,

Numa das rampas laterais de terra cinzenta da autopista, parentes de desaparecidos haviam desenhado o contorno de uma figura humana com latinhas de óleo cru. Em datas importantes, o óleo era aceso para que de longe se visse a "silhueta" - como passou a ser conhecido aquele lugar de memória. No local, numa placa de madeira fixada em toras de eucalipto, dezenas de fotos mostravam os rostos dos que haviam estado entre aqueles muros. (PILLA, 2015, p.13).

A citaçâo evidencia a importância de existir lugares que conservem a memória a fim de que năo só os familiares possam realizar o seu luto, mas também para que as novas geraçóes tenham a oportunidade de conhecer a história dos opositores às ditaduras. Desse modo, esse local, como outros na Argentina, possibilita o cumprimento do dever de memória proposto por Ricouer (2007) e pensamos que deveria servir de exemplo às demais naçōes latino-americanas. Curiosamente, no Brasil, só identificamos um espaço de memória localizado em Sáo Paulo, um sinal do descaso oficial com nosso passado traumático.

Consideramos que, enquanto a Lei da Anistia năo for revista, a literatura brasileira precisará continuar a exercer o papel de arquivo da ditadura. Nesse processo, acreditamos que seria produtivo que novas vozes femininas viessem à tona para que a nossa história fosse vista de distintas perspectivas. No romance de Pilla, conhecemos a história de duas măes cujos filhos foram assassinados pelos governos autoritários, Iracema e Cachita, sendo que a primeira é brasileira e a segunda, argentina. Também fomos apresentados à Júlia e Emilia, militantes de esquerda, respectivamente, na Argentina e no Uruguai. Além disso, a protagonista participou de grupos políticos no Brasil e na Argentina. Dessa maneira, a narrativa recupera a presença das mulheres latino-americanas nas lutas contra os governos ditatoriais em nosso continente, tanto no papel de mâes que buscam justiça pela morte de seus filhos quanto no de integrantes de partidos ou movimentos políticos. Nesse sentido, podemos classificar a escritora gaúcha como uma guardiă da memória da resistência feminina do Cone sul, pois deu visibilidade a um grupo que foi (quase) apagado de nossa história. Além disso, humanizou as presas políticas, ressaltando sua solidariedade e sensibilidade às artes, desconstruindo a ideia de sua "periculosidade", veiculada pelos órgâos de repressâo.

Constatamos que a história pessoal da autora/protagonista se conecta com a de nosso continente, visto que ela resgata episódios históricos marcantes. Entre eles, destacam-se as denúncias das desventuras ditatoriais que assolaram vários países no século passado e ameaçam a consolidaçăo da democracia na América Latina. Percebemos que a violaçâo aos direitos humanos foi uma marca dos regimes autoritários latino-americanos, representada pelas cruéis açôes da Operaçâo Condor, da OBAN e da AAA. 
Ao ler o livro de Pilla o leitor tem a oportunidade de conhecer um painel de nossa história que abarca o período de 1950 a 2011. Desse modo, além de desvendar a conexăo entre os grupos opressivos que atuaram em nosso continente, também entrará em contato com autores da literatura latino-americana que, tais como Marighella e Walsh, adotaram a arte como forma de resistência e exerceram o papel de intelectuais comprometidos com o seu tempo. Portanto, perceberá que havia uma rede de solidariedade entre os militantes na América Latina que lutaram por um mundo melhor, na qual as mulheres tiveram uma relevante participaçăo.

Acreditamos que, ao humanizar os militantes de esquerda e denunciar o terrorismo do estado, a autora desconstrói a imagem estereotipada das mulheres e homens que resistiram às ditaduras latino-americanas, caracterizados como "subversivos" pelos repressores. Nessa perspectiva, após escutarmos suas vozes, reforçamos nossa convicçâo da importância da continuidade da luta pela memória, verdade e justiça às vítimas da ditadura e aos seus familiares em nosso país. Assim, esperamos que o presente trabalho instigue outras investigaçōes sobre esta temática.

Na epígrafe que fecha este estudo, a escritora gaúcha avalia que a Comissáo Nacional da Verdade objetivou mostrar como era a ditadura brasileira. Contudo, para ela, o mais significativo foi ter recebido os pedidos de desculpa que foram feitos na Anistia. Esperamos que as outras metas da CNV sejam atendidas e que os arquivos das Forças Armadas sobre o período do horror sejam abertos, possibilitando o esclarecimento de vários crimes e a puniçăo de seus responsáveis a fim de que os resquícios da ditadura possam ser eliminados de nossa sociedade. Para que isso se efetive, pensamos que é preciso escolher um governo cujo slogan seja Democracia acima de tudo! 


\section{REFERÊNCIAS}

COLLING, A. M. 50 anos da ditadura militar no Brasil: questôes feministas e de gênero. Opsis, n. 2, v.15, dez. 2015.

DALCASTAGNÉ, R. 0 espaço da dor. Brasília: Ed. UNB, 1996.

ESTEVES, A. 0 romance histórico brasileiro contemporâneo (1975-2000). Săo Paulo: Ed. UNESP, 2010.

FIGUEIREDO, E. Mulheres ao espelho: autobiografia, ficçăo, autoficçăo. Rio de Janeiro, EdUERJ, 2013.

FIGUEIREDO, E. A literatura como arquivo da ditadura brasileira. Rio de Janeiro: 7 Letras, 2017.

LÍSIAS, R. Literatura brasileira e os tempos da ditadura. Recife: Suplemento Pernambuco, 2018. Disponível em: https://www.suplementopernambuco.com.br/edi\%C3\%A7\%C3\%B5es-anteriores/77-capa/2166-literatura-brasileira-e-os-tempos-da-ditadura. html Acesso em: 30 mar. 2020.

PILLA, M. Volto semana que vem. Sáo Paulo: Cosac Naify, 2015.

PILLA, M; PAIM, L.; PORTO, A. Maria Regina Pilla relembra momentos da ditadura e de tortura, sem rancor ou truculência. Porto Alegre: Jornal Sul21, 15 nov. 2015. Disponível em: http://www.sul21.com.br/jornal/maria-regina-pilla-relembramomentos-da-ditadura-e-de-tortura-sem-rancor-ou-truculencia/ Acesso em: 10 abr. 2020.

PRADO, M. L.; PELEGRINO, G. História da América Latina. Săo Paulo: Contexto, 2014.

RAGO, M. Desejo de memória. Labrys, n. 15-16, dez. 2009.

RICOUER, P. A memória, a história, o esquecimento. Traduçâo de Alain François et.al. Campinas: Editora da UNICAMP, 2007.

SAMOUYAULT, T. A intertextualidade. Sāo Paulo: Aderaldo \& Rothischild, 2008.

TELES, E.; SAFATLE, V. O que resta da ditadura: a exceçăo brasileira. Sáo Paulo: Boitempo, 2010.

WALSH, R. Carta abierta de un escritor a la Junta Militar. In: Operación masacre. Buenos Aires: Ediciones de la Flor, 2001.

WEINHARDT, M. Filhos da geraçăo de 1960-70: herdeiros da memória. In: Ficçōes contemporâneas: história e memória. Ponta Grossa: Ed. UEPG, 2015. 